University of Wollongong

Research Online

Australian Institute for Innovative Materials -

Papers

Australian Institute for Innovative Materials

2014

Direct synthesis of RGO/Cu2O composite films on Cu foil for supercapacitors

Xiangmao Dong

East China University of Science and Technology

Kun Wang

Jiangsu University

Chongjun Zhao

University of Wollongong, chongjunzhao@ecust.edu.cn

Xiuzhen Qian

East China University of Science and Technology

Shi Chen

Wuhan University of Technology

See next page for additional authors

Follow this and additional works at: https://ro.uow.edu.au/aiimpapers

Part of the Engineering Commons, and the Physical Sciences and Mathematics Commons

Research Online is the open access institutional repository for the University of Wollongong. For further information contact the UOW Library: research-pubs@uow.edu.au 


\title{
Direct synthesis of RGO/Cu2O composite films on Cu foil for supercapacitors
}

\author{
Abstract \\ Reduced graphene oxide/cuprous oxide (RGO/Cu2O) composite films were directly synthesized on the \\ surface of copper foil substrates through a straight redox reaction between $\mathrm{GO}$ and $\mathrm{Cu}$ foil via a \\ hydrothermal approach. Characterization of the resultant composites with X-ray diffraction, Raman \\ spectroscopy, X-ray photoelectron spectroscopy, and field emission scanning electron microscope \\ (FESEM) confirms the formation of Cu2O and reduction of GO, in which $\mathrm{Cu} 2 \mathrm{O}$ nanoparticles were well \\ covered by RGO. The resultant composites (referred to as RGO/Cu2O/Cu) were directly used as \\ electrodes for supercapacitors, and their electrochemical performance was assessed by cyclic \\ voltammetry (CV), galvanostatic charge-discharge (GCD), and electrochemical impedance spectrometry \\ (EIS) in $1 \mathrm{M} \mathrm{KOH}$ aqueous solution. A specific capacitance of $98.5 \mathrm{~F} \mathrm{~g}-1$ at $1 \mathrm{~A} \mathrm{~g}-1$ was obtained, which \\ is much higher than that of pure Cu2O prepared under the same conditions, due to the presence of RGO.

\section{Keywords} \\ supercapacitors, synthesis, rgo, cu2o, composite, films, cu, foil, direct \\ Disciplines \\ Engineering | Physical Sciences and Mathematics

\section{Publication Details} \\ Dong, X., Wang, K., Zhao, C., Qian, X., Chen, S., Li, Z., Liu, H. \& Dou, S. (2014). Direct synthesis of RGO/ \\ Cu2O composite films on Cu foil for supercapacitors. Journal of Alloys and Compounds, 586 745-753.

\section{Authors} \\ Xiangmao Dong, Kun Wang, Chongjun Zhao, Xiuzhen Qian, Shi Chen, Zhen Li, Hua-Kun Liu, and S X. Dou
}




\title{
Direct synthesis of $\mathrm{RGO} / \mathrm{Cu}_{2} \mathrm{O}$ composite films on $\mathrm{Cu}$ foil for
}

\section{supercapacitors}

\author{
Xiangmao Dong ${ }^{\mathrm{a}}$, Kun Wang ${ }^{\mathrm{a}}$, Chongjun Zhao ${ }^{\mathrm{a}, \mathrm{b}}$, Xiuzhen Qian ${ }^{\mathrm{a}}$, Shi Chen ${ }^{\mathrm{c}}$, Zhen Li*b, \\ Huakun Liu ${ }^{\mathrm{b}}$, Shixue Dou ${ }^{\mathrm{b}}$ \\ ${ }^{a}$ Key Laboratory for Ultrafine Materials of the Ministry of Education, Shanghai Key Laboratory of Advanced \\ Polymeric Materials, School of Materials Science and Engineering, East China University of Science and \\ Technology, Shanghai 200237, P.R. ChinaTel: +86-21-6425 0838; Fax: +86-21-6425 0838; E-mail: \\ chongjunzhao@ecust.edu.cn
}

${ }^{b}$ Institute for Superconducting and Electronic Materials, University of Wollongong, Wollongong 2500, Australia. Tel: +61-2-4221-5163; Fax: +61-2-4221-5731; E-mail: zhenl@uow.edu.au ${ }^{c}$ School of Information Engineering, Wuhan University of Technology, Wuhan, 430070 


\section{ABSTRACT}

Reduced graphene oxide/cuprous oxide $\left(\mathrm{RGO} / \mathrm{Cu}_{2} \mathrm{O}\right)$ composite films were directly synthesized on the surface of copper foil substrates through a straight redox reaction between $\mathrm{GO}$ and $\mathrm{Cu}$ foil via a hydrothermal approach. Characterization of the resultant composites with X-ray diffraction, Raman spectroscopy, X-ray photoelectron spectroscopy, and field emission scanning electron microscope (FESEM) confirms the formation of $\mathrm{Cu}_{2} \mathrm{O}$ and reduction of $\mathrm{GO}$, in which $\mathrm{Cu}_{2} \mathrm{O}$ nanoparticles were well covered by RGO. The resultant composites (referred to as $\mathrm{RGO} / \mathrm{Cu}_{2} \mathrm{O} / \mathrm{Cu}$ ) were directly used as electrodes for supercapacitors, and their electrochemical performance was assessed by cyclic voltammetry (CV), galvanostatic charge-discharge (GCD), and electrochemical impedance spectrometry (EIS) in $1 \mathrm{M} \mathrm{KOH}$ aqueous solution. A specific capacitance of $98.5 \mathrm{~F} \mathrm{~g}^{-1}$ at $1 \mathrm{~A} \mathrm{~g}^{-1}$ was obtained, which is much higher than that of pure $\mathrm{Cu}_{2} \mathrm{O}$ prepared under the same conditions, due to the presence of RGO.

Keywords: $\mathrm{RGO} / \mathrm{Cu}_{2} \mathrm{O} / \mathrm{Cu}$ composites; Thin films; Hydrothermal synthesis; Supercapacitors 


\section{Introduction}

Over the past several decades, supercapacitors (also called electrochemical capacitors) have been attracting considerable attention due to their higher power density, shorter charging time, higher cycling efficiency, and longer lifetime in comparison with batteries [1-5]. They also have higher energy density than conventional dielectric capacitors. Therefore, supercapacitors are one of the most promising energy storage devices and power suppliers for digital products, hybrid-electric vehicles, and other portable electronic devices [6]. Their energy density $\left(0.5-10 \mathrm{~W} \mathrm{~h} \mathrm{~kg}^{-1}\right)$ is still lower than that of batteries, however, and many efforts have been made to improve it to the point of being at least comparable to that of batteries. One efficient approach is the use of electrode materials which have a similar battery-type Faradaic current profile. Certain metal oxides and hydroxides, especially transition metal oxides or hydroxides, and organic materials, including conducting polymers, can meet this requirement and serve as electrode materials for supercapacitors. One promising candidate is $\mathrm{RuO}_{2}$, and the fabricated supercapacitors have a specific capacitance of $1340 \mathrm{~F} \mathrm{~g}^{-1}$ and a specific energy of $7.5 \mathrm{~W} \mathrm{~h} \mathrm{~kg}^{-1}[7,8]$. $\mathrm{RuO}_{2}$ is very expensive [8,9], however, and the use of cost-effective transition metal oxides such as $\mathrm{MnO}_{2}, \mathrm{SnO}_{2}, \mathrm{TiO}_{2}$ and $\mathrm{Ni}(\mathrm{OH})_{2}$ as alternatives has been investigated [10-13]. Most pure metal oxides or hydroxides suffer from some intrinsic disadvantages, however, such as mechanical brittleness, chemical instability, and low conductivity, which limit their application in flexible electrochemical energy storage devices $[14,15]$. 
The above disadvantages of metal oxides or hydroxides could be overcome by combining them with versatile graphene to form composites, as graphene is a two-dimensional (2D) material with extraordinary electrical, and mechanical properties [16], large surface area and high chemical stability. On the one hand, the high mechanical elasticity of graphene (elastic modulus is about $1 \mathrm{TPa}$ ) [17], which has been used in the fields of nanoelectronics and spintronics, can improve the flexibility of composites $[18,19]$. The intrinsic high electrical conductivity (2420 S $\left.\mathrm{m}^{-1}\right)$ and large specific surface area $\left(2630 \mathrm{~m}^{2} \mathrm{~g}^{-1}\right)$ of graphene could endow supercapacitors with high specific power $[14,18]$. On the other hand, metal oxide (or metal hydroxide) nanoparticles could act as spacers in the interlayers of graphene sheets to prevent them from aggregation, increasing the interplanar spacing and contact area with the electrolyte [20].

Up to now, some transition metal oxides, hydroxides (including those with variable valence), and their composites with graphene have been widely used in energy storage. Among the transition metal oxides, $\mathrm{Cu}_{2} \mathrm{O}$ (or $\mathrm{CuO}$ ) as an abundant metal oxide has been investigated as an electrode material for Li ion batteries (LIBs) [21], due to its high theoretical capacity, low cost, and environmental friendliness. Copper oxide composites with graphene have been also used in LIBs [22-34]. Their application in batteries suggests the feasibility of their application in supercapacitors, as similar Faradaic redox reactions to those in LIBs are also used in supercapacitors. There are only a few reports on this aspect [35-37], however, in which reduced graphene oxide/cuprous oxide $\left(\mathrm{RGO} / \mathrm{Cu}_{2} \mathrm{O}\right)$ composites were usually prepared from 
copper salts with graphene oxide [33-35, 38, 39], and the resultant $\mathrm{RGO} / \mathrm{Cu}_{2} \mathrm{O}$ or $\mathrm{RGO} / \mathrm{CuO}$ powder has to be carefully washed due to the presence of residual cations. This rinsing process can be omitted when elemental $\mathrm{Cu}$ is used as the $\mathrm{Cu}$ source for $\mathrm{RGO} / \mathrm{Cu}_{2} \mathrm{O}$ composites, because $\mathrm{Cu}$ can be oxidized into $\mathrm{Cu}_{2} \mathrm{O}$ or $\mathrm{CuO}$, and $\mathrm{GO}$ can be reduced to RGO. There is no other by-product formed.

Herein, we directly synthesized $\mathrm{RGO} / \mathrm{Cu}_{2} \mathrm{O}$ nanocomposite films on $\mathrm{Cu}$ foil substrates through a hydrothermal process, in which the formation of $\mathrm{Cu}_{2} \mathrm{O}$ nanoparticles (NPs) and the reduction of GO simultaneously took place in an one-pot reaction, and the formed $\mathrm{Cu}_{2} \mathrm{O}$ NPs were covered with reduced graphene oxide (RGO) sheets. The resultant sandwich composites (i.e. $\mathrm{RGO} / \mathrm{Cu}_{2} \mathrm{O} / \mathrm{Cu}$ ) were then used as electrodes in supercapacitors, and showed excellent electrochemical performance due to their unique structure, in which $\mathrm{Cu}_{2} \mathrm{O}$ nanoparticles formed in-situ on the surface of $\mathrm{Cu}$ foil. The reduced graphene oxide notably improved the capacity of the $\mathrm{RGO} / \mathrm{Cu}_{2} \mathrm{O} / \mathrm{Cu}$ electrodes.

\section{Experimental}

\subsection{Materials and reagents}

Pristine graphite powder, hydrochloric acid ( $\mathrm{HCl}, 36.0-38.0 \mathrm{wt} \%)$, hydrogen peroxide $\left(\mathrm{H}_{2} \mathrm{O}_{2}, 30 \mathrm{wt} \%\right)$, sulfuric acid $\left(\mathrm{H}_{2} \mathrm{SO}_{4}, 95-98 \mathrm{wt} \%\right)$, potassium permanganate $\left(\mathrm{KMnO}_{4}\right)$, phosphorus pentoxide $\left(\mathrm{P}_{2} \mathrm{O}_{5}\right)$, potassium persulfate $\left(\mathrm{K}_{2} \mathrm{~S}_{2} \mathrm{O}_{8}\right)$ and ethanol $\left(\mathrm{C}_{2} \mathrm{H}_{5} \mathrm{OH},>99.7 \mathrm{wt} \%\right)$ were obtained from the Shanghai Chemical Company. Copper substrates were obtained from Alfa Aesar. All chemical reagents were used as 
received without any further purification. Water used in all syntheses was distilled and deionized.

\subsection{Preparation of graphene oxide}

GO was synthesized by a modified Hummer's method [40, 41]. Briefly, graphite powder ( $3 \mathrm{~g}, 325$ mesh) was put into an $80{ }^{\circ} \mathrm{C}$ solution of concentrated $\mathrm{H}_{2} \mathrm{SO}_{4}(12$ $\mathrm{mL}), \mathrm{K}_{2} \mathrm{~S}_{2} \mathrm{O}_{8}(2.5 \mathrm{~g})$, and $\mathrm{P}_{2} \mathrm{O}_{5}(2.5 \mathrm{~g})$. The mixture was kept at $80{ }^{\circ} \mathrm{C}$ for $4.5 \mathrm{~h}$. Then, the mixture was diluted with $500 \mathrm{~mL}$ of de-ionized (DI) water and left overnight. The mixture was filtered and washed with water to remove the residual acid. The product was dried under ambient conditions overnight.

Pre-oxidized graphite powder was added into cold $\left(0{ }^{\circ} \mathrm{C}\right)$ concentrated $\mathrm{H}_{2} \mathrm{SO}_{4}$ $(120 \mathrm{~mL})$. Then, $\mathrm{KMnO}_{4}(15 \mathrm{~g})$ was slowly added, with the temperature of mixture kept below $20{ }^{\circ} \mathrm{C}$. After addition of $250 \mathrm{~mL}$ of water, the mixture was stirred for $2 \mathrm{~h}$, and then an additional $700 \mathrm{~mL}$ of water was added. After that, $20 \mathrm{~mL}$ of $30 \% \mathrm{H}_{2} \mathrm{O}_{2}$ was added into the mixture, and the solution changed into brilliant yellow, accompanied by the generation of bubbles. The mixture was filtered and washed with diluted $\mathrm{HCl}$ aqueous solution $(10 \mathrm{wt} \%, 1 \mathrm{~L})$ to remove metal ions. The brownish yellow solution was centrifuged at $10000 \mathrm{rpm}$, the supernatant solution was decanted away, and the resulting material was subjected to multiple washings with water until the $\mathrm{pH}$ was 7 . The obtained GO was dispersed in a certain amount of water.

\subsection{Preparation of $\mathrm{RGO} / \mathrm{Cu}_{2} \mathrm{O}$ composites on copper sheets}

In a typical procedure, highly pure copper substrates (99.99\%) were carefully cleaned with acetone, ethanol, and water, respectively, in an ultrasound bath to 
remove surface impurities. The as-synthesized GO (30 mg), which was dispersed in deionized water $(50 \mathrm{ml})$, was sonicated for $1 \mathrm{~h}$. Cleaned copper foil substrates $(1 \times 2$ $\mathrm{cm}^{2}$ ) were put into the above GO solution and stirred for $1 \mathrm{~h}$. The mixture was loaded into a $100 \mathrm{ml}$ Teflon-lined stainless steel autoclave for hydrothermal reaction at a selected temperature for $24 \mathrm{~h}$. The final product was washed with ethanol and water, and dried in an oven at $60{ }^{\circ} \mathrm{C}$ for $12 \mathrm{~h}$. In order to study the effects of temperature on the formation of the $\mathrm{RGO} / \mathrm{Cu}_{2} \mathrm{O}$ composites, a series of samples were prepared at $160{ }^{\circ} \mathrm{C}, 180{ }^{\circ} \mathrm{C}, 200{ }^{\circ} \mathrm{C}, 220^{\circ} \mathrm{C}$, and $240{ }^{\circ} \mathrm{C}$, respectively, which were designated as $\mathrm{RGO} / \mathrm{Cu}_{2} \mathrm{O} / \mathrm{Cu}-160, \mathrm{RGO} / \mathrm{Cu}_{2} \mathrm{O} / \mathrm{Cu}-180, \mathrm{RGO} / \mathrm{Cu}_{2} \mathrm{O} / \mathrm{Cu}-200, \mathrm{RGO} / \mathrm{Cu}_{2} \mathrm{O} / \mathrm{Cu}-220$, and $\mathrm{RGO} / \mathrm{Cu}_{2} \mathrm{O} / \mathrm{Cu}-240$, according to the preparation temperature. In the absence of copper or $\mathrm{GO}, \mathrm{Cu}_{2} \mathrm{O} / \mathrm{Cu}-200$ films and $\mathrm{RGO}$ powder were obtained via a similar process at $200{ }^{\circ} \mathrm{C}$.

\subsection{Characterizations}

Wide-angle $\left(10^{\circ}-80^{\circ}\right)$ powder X-ray diffraction $(\mathrm{XRD})$ was carried out using a polycrystalline X-ray diffractometer (RIGAKU, D/MAX 2550 VB/PC, 40 kV/200 $\mathrm{mA}, \lambda \alpha_{1}=1.5406 \AA$ ) at room temperature. Fourier transform infrared (FTIR) spectra were collected on a NICOLET 6700 FTIR spectrophotometer. To demonstrate the particle uniformity and morphology, all samples were examined by field emission scanning electron microscopy (FESEM) using a JEOL SM-6360LV microscope. Raman spectra were collected on an INVIA Raman microprobe (Renishaw Instruments, England) with 514 nm laser excitation. X-ray photoelectron spectroscopy (XPS) measurements were performed on a Perkin-Elmer PHI5000CESCA system 
with a base pressure of $10^{-9}$ Torr.

\subsection{Electrochemical measurements}

$\mathrm{RGO} / \mathrm{Cu}_{2} \mathrm{O} / \mathrm{Cu}$ composites were dried under vacuum at $60{ }^{\circ} \mathrm{C}$ for $12 \mathrm{~h}$, and then directly used as working electrodes, with each having an area of $1 \times 1 \mathrm{~cm}^{2}$. The electrolyte was $1 \mathrm{M} \mathrm{KOH}$ aqueous solution. Three-electrode cells were constructed consisting of an as-fabricated working electrode, a counter electrode (Pt foil, $2 \times 3 \mathrm{~cm}^{2}$ ), and a reference saturated calomel electrode (SCE). The capacitive performances of all electrodes were evaluated with an electrochemical work-station (CHI660E, Shanghai) using cyclic voltammetry, chronopotentiometry, and AC impedance tests. After the performance tests were finished, the $\mathrm{RGO} / \mathrm{Cu}_{2} \mathrm{O} / \mathrm{Cu}$ electrodes were sonicated for 30 min, and then subjected to hydrochloric acid (10\% wt.) and sonicated for another 10 min. Thus, the loading amount of $\mathrm{RGO} / \mathrm{Cu}_{2} \mathrm{O}$ was determined from the weight difference of the electrodes before testing and after ultrasonication, which was controlled at about $2 \mathrm{mg}$.

\section{Results and discussion}

The obtained $\mathrm{RGO} / \mathrm{Cu}_{2} \mathrm{O} / \mathrm{Cu}$ composites were characterized with state-of-the-art facilities. Fig.1 shows the X-ray diffraction (XRD) patterns of the bare $\mathrm{Cu}$ foil substrates, the $\mathrm{RGO}$ powder, and the $\mathrm{RGO} / \mathrm{Cu}_{2} \mathrm{O} / \mathrm{Cu}$ composites prepared at different temperatures, respectively. Three peaks centered at $43.2^{\circ}, 50.4^{\circ}$, and $73.4^{\circ}$, assigned to the (111), (200), and (220) planes of metallic copper [42], can be clearly observed in the patterns of the copper foil and the $\mathrm{RGO} / \mathrm{Cu}_{2} \mathrm{O} / \mathrm{Cu}$ composites. The presence of 
$\mathrm{Cu}$ diffraction peaks in the composites suggests that the $\mathrm{Cu}$ foil substrates were not entirely used up in these samples. Five new characteristic diffraction peaks at $29.3^{\circ}$, $36.2^{\circ}, 42^{\circ}, 61.1^{\circ}$, and $73.9^{\circ}$ in the composites correspond to the (110), (111), (200), (220), and (311) crystalline planes of cubic $\mathrm{Cu}_{2} \mathrm{O}$, respectively (JCDS 78-2076) [43]. In addition, the relative intensity of the strongest diffraction peak of $\mathrm{Cu}_{2} \mathrm{O}$ (i.e., (111) at $2 \theta=36.2^{\circ}$ ) increases with increasing temperature. These results indicate the formation of cubic $\mathrm{Cu}_{2} \mathrm{O}$ particles on the surface of the $\mathrm{Cu}$ foil after the hydrothermal treatment, and their crystallinity increases with increasing temperature. It should be noted that the broad peak of $\mathrm{RGO}$ at $23.7^{\circ}$ is negligible, due to the strong peaks of $\mathrm{Cu}$ and $\mathrm{Cu}_{2} \mathrm{O}$.

The formation of $\mathrm{Cu}_{2} \mathrm{O}$ indicated by the XRD results suggests the occurrence of redox reactions, which can be reflected by the change in the molecular vibrations in the reagents and products. Fig.2 compares the FTIR spectra of the $\mathrm{RGO} / \mathrm{Cu}_{2} \mathrm{O}$ composite films with that of GO. The GO spectrum shows the presence of various oxygen-containing groups. The peaks at $1701 \mathrm{~cm}^{-1}, 1219 \mathrm{~cm}^{-1}$, and $1049 \mathrm{~cm}^{-1}$ are assigned to $\mathrm{C}=\mathrm{O}, \mathrm{C}-\mathrm{O}$, and $\mathrm{C}-\mathrm{O}-\mathrm{C}$ vibrations, respectively. The peak at $1621 \mathrm{~cm}^{-1}$ is due to the skeletal vibration of un-oxidized graphitic domains or the remaining $\mathrm{sp}^{2}$ carbon character of graphite [44]. Most contributions from oxygen-containing groups decrease or disappear after hydrothermal treatment, which demonstrates that GO has been reduced by the $\mathrm{Cu}$ foil. In addition, the characteristic peak of the copper-oxygen stretching vibration in the $\mathrm{Cu}_{2} \mathrm{O}$ is observed at $624 \mathrm{~cm}^{-1}[45,46]$.

In order to further prove the reduction of $\mathrm{GO}$ during hydrothermal treatment, 
Raman spectroscopy was used to characterize these samples (Fig.3). The ratio of the D band $\left(\sim 1350 \mathrm{~cm}^{-1}\right)$, originating from disorder-activated Raman mode, to the $\mathrm{G}$ band $\left(\sim 1596 \mathrm{~cm}^{-1}\right)$, corresponding to $\mathrm{sp}^{2}$ hybridized carbon, is usually used to semi-quantitatively determine the extent of reduction [47]. The slight increase in the $\mathrm{D} / \mathrm{G}$ ratio from $0.89(\mathrm{GO})$ to $0.95(\mathrm{RGO})$ suggests a decrease in the average size of the $\mathrm{sp}^{2}$ domains upon reduction. This means that RGO has a small size and a large quantity of edges, which act as defects and lead to the increase in the D band [48]. Compared with pure $\mathrm{RGO}$, higher $\mathrm{D} / \mathrm{G}$ ratios are obtained for the composites, i.e. $\mathrm{RGO} / \mathrm{Cu}_{2} \mathrm{O} / \mathrm{Cu}-160$ (1.18), $\mathrm{RGO} / \mathrm{Cu}_{2} \mathrm{O} / \mathrm{Cu}-180$ (1.25), $\mathrm{RGO} / \mathrm{Cu}_{2} \mathrm{O} / \mathrm{Cu}-200$ (1.16), $\mathrm{RGO} / \mathrm{Cu}_{2} \mathrm{O} / \mathrm{Cu}-220$ (1.11), and $\mathrm{RGO} / \mathrm{Cu}_{2} \mathrm{O} / \mathrm{Cu}-240$ (1.22), indicating that $\mathrm{RGO}$ was deeply reduced to form more disordered structure during the hydrothermal process with the assistance of copper [49]. In addition, the peak at $2696 \mathrm{~cm}^{-1}$, corresponding to the overtone of the $2 \mathrm{D}$ band, red-shifts to a higher wave number and becomes broader, which indicates the multilayer structure of RGO in the composites [50]. The peak observed at $2932 \mathrm{~cm}^{-1}$ is associated with the $\left(D+D^{\prime}\right)$ band and attributed to defects [47]. It should be noted that the Raman peaks of $\mathrm{Cu}_{2} \mathrm{O}$ in the $\mathrm{RGO} / \mathrm{Cu}_{2} \mathrm{O} / \mathrm{Cu}$ composites were not observed because the internal $\mathrm{Cu}_{2} \mathrm{O}$ layer is well covered by the RGO film as shown in the SEM images (Fig.5 and Fig.6).

Fig.4(a-c) shows the $\mathrm{C} 1 \mathrm{~s}$ spectra of $\mathrm{GO}, \mathrm{RGO}$, and $\mathrm{RGO} / \mathrm{Cu}_{2} \mathrm{O} / \mathrm{Cu}-200$, respectively. They could be deconvoluted into three peaks at 284.78, 286.97, and 288. $77 \mathrm{eV}$, which are associated with $\mathrm{C}-\mathrm{C}, \mathrm{C}-\mathrm{O}$, and $\mathrm{C}=\mathrm{O}$, respectively. The peak intensities of $\mathrm{C}-\mathrm{O}$ and $\mathrm{C}=\mathrm{O}$ are much stronger in $\mathrm{GO}$ (Fig.4a), but they are drastically 
reduced after hydrothermal treatment (Fig.4b). The relative intensity of $\mathrm{C}=\mathrm{O}$ in the $\mathrm{RGO} / \mathrm{Cu}_{2} \mathrm{O} / \mathrm{Cu}-200$ is smaller than that in the pure $\mathrm{RGO}$, indicating that a deeper reduction occurred in the presence of copper foil (Fig.4c).

The $\mathrm{C} / \mathrm{O}$ ratios for these samples are calculated to be 1.54 (GO), 2.87 (RGO), 3.08 (RGO/Cu $2 \mathrm{O} / \mathrm{Cu}-160), 3.56\left(\mathrm{RGO} / \mathrm{Cu}_{2} \mathrm{O} / \mathrm{Cu}-180\right), 2.55\left(\mathrm{RGO} / \mathrm{Cu}_{2} \mathrm{O} / \mathrm{Cu}-200\right), 3.12$ $\left(\mathrm{RGO} / \mathrm{Cu}_{2} \mathrm{O} / \mathrm{Cu}-220\right)$, and $3.00\left(\mathrm{RGO} / \mathrm{Cu}_{2} \mathrm{O} / \mathrm{Cu}-240\right)$, respectively (Fig.4d). The results demonstrate the deeper reduction of $\mathrm{GO}$ in the composites than in the pure GO, which is consistent with the Raman results.

For $\mathrm{Cu}$ foil (Fig.4e, bottom), there are two small peaks at 944.20 and $962.63 \mathrm{eV}$ (marked with arrows) besides the main $\mathrm{Cu} 2 \mathrm{p}_{1 / 2}(932.52 \mathrm{eV})$ and $\mathrm{Cu} 2 \mathrm{p}_{3 / 2}(952.53 \mathrm{eV})$ peaks, which indicates a thin oxide coating on the $\mathrm{Cu}$ surface [51]. The $\mathrm{Cu} 2 \mathrm{p}$ of $\mathrm{RGO} / \mathrm{Cu}_{2} \mathrm{O} / \mathrm{Cu}-200$ (Fig.4e, top) contains two main peaks at $932.95 \mathrm{eV}$ and $952.68 \mathrm{eV}$, corresponding to the $\mathrm{Cu} 2 \mathrm{p}_{3 / 2}$ and $\mathrm{Cu} 2 \mathrm{p}_{1 / 2}$ peaks of $\mathrm{Cu}(\mathrm{I})[52,53]$ and/or $\mathrm{Cu}(0)$, respectively. Similar to the spectrum of $\mathrm{Cu}$ foil, a weak $\mathrm{Cu}$ (II) signal was detected owing to the oxidation after the exposure of the $\mathrm{Cu}_{2} \mathrm{O} / \mathrm{RGO}$ sample to air [54]. Although the binding energies of $\mathrm{Cu}$ and $\mathrm{Cu}_{2} \mathrm{O}$ in the XPS spectra are similar, they can be distinguished from their LMM-2 Auger transitions, as displayed in Fig.4f. The binding energies at $570 \mathrm{eV}$ and $568 \mathrm{eV}$ corresponding to $\mathrm{Cu}(\mathrm{I})$ and $\mathrm{Cu}(0)$ are clearly distinguished [55].

In the FESEM images of $\mathrm{RGO} / \mathrm{Cu}_{2} \mathrm{O} / \mathrm{Cu}-200$ (Fig.5a, 5c), spheroidal $\mathrm{Cu}_{2} \mathrm{O}$ particles with a size of $200-800 \mathrm{~nm}$ that were covered by graphene sheets are clearly observed. Smaller cubic particles $(\sim 200 \mathrm{~nm})$ on top of big particles were obtained 
under the same hydrothermal treatment, however, in the absence of GO (Fig.5b). Therefore, the presence of GO drastically influences the morphology and size of the $\mathrm{Cu}_{2} \mathrm{O}$ particles [48], i.e. the particle size increased from $200 \mathrm{~nm}$ to $\sim 800 \mathrm{~nm}$, accompanied by a change of shape from spheroidal into cubic. Another reference sample was obtained by the same hydrothermal treatment of GO in the absence of $\mathrm{Cu}$ foil (Fig.5d). Aggregated and crumpled RGO sheets formed thick flakes with negligible separation, which is consistent with the previous report [56]. This indicates that the introduction of $\mathrm{Cu}$ foil and the formation of $\mathrm{Cu}_{2} \mathrm{O}$ efficiently facilitate spreading of the RGO sheets on the surface of the $\mathrm{Cu}_{2} \mathrm{O}$ layer, providing a large surface area for electrochemical activities.

Fig.6 shows FESEM images of the $\mathrm{RGO} / \mathrm{Cu}_{2} \mathrm{O} / \mathrm{Cu}$ composites prepared at other temperatures. From their top-view images (Fig.6(a, c, e, g)), there is no obvious difference among them, except for a slight increase in the $\mathrm{Cu}_{2} \mathrm{O}$ particle size with increasing temperature. The $\mathrm{Cu}_{2} \mathrm{O}$ particles are always covered by the $\mathrm{RGO}$ sheets. There is a big difference, however, in the RGO films, which can be observed from their tilted-view images (Fig.6(b, d, f, h)). At low temperature (e.g. $160{ }^{\circ} \mathrm{C}$ ), the RGO film is very thin and disconnected (forming islands). With the temperature increased from $160{ }^{\circ} \mathrm{C}$ to $180{ }^{\circ} \mathrm{C}$, the RGO film becomes slightly thicker, and the RGO sheets connected with each other (Fig.6d). When the temperature reaches $200{ }^{\circ} \mathrm{C}$, a flat net-like structure appears (Fig.5c). A further increase in temperature to $220{ }^{\circ} \mathrm{C}$ leads to a broken film due to the formation of large $\mathrm{Cu}_{2} \mathrm{O}$ particles. When the temperature further increases to $240{ }^{\circ} \mathrm{C}$, a thick $\mathrm{Cu}_{2} \mathrm{O}$ layer forms accompanied by a thin $\mathrm{RGO}$ 
film. Obviously, a more continuous and thinner RGO is favorable for the transfer of electrons and electrolyte during electrochemical testing [57]. Therefore, the optimum reaction temperature is $200{ }^{\circ} \mathrm{C}$.

On the basis of the above results, we propose the following formation mechanism (Scheme 1). Firstly, $\mathrm{Cu}$ foil substrates could react with water under hydrothermal conditions to form $\mathrm{Cu}(\mathrm{OH})$ and produce reactive hydrogen $\left(\mathrm{H}^{*}\right)$ or hydrogen $\left(\mathrm{H}_{2}\right)$. Then, both $\mathrm{H}^{*}$ and $\mathrm{H}_{2}$ can reduce the $-\mathrm{COOH}$ and $-\mathrm{OH}$ groups of $\mathrm{GO}$ into $-\mathrm{OH}$ and $\mathrm{H}_{2} \mathrm{O}$, and $\mathrm{GO}$ becomes RGO. Meanwhile, $\mathrm{Cu}(\mathrm{OH})$ is dehydrated under hydrothermal conditions to form $\mathrm{Cu}_{2} \mathrm{O}$ and $\mathrm{H}_{2} \mathrm{O}$. The possible reactions involved in the hydrothermal process are summarized in Eqs. (1)-(4).

$$
\begin{aligned}
& \mathrm{Cu}+\mathrm{H}_{2} \mathrm{O} \leftrightarrow \mathrm{Cu}(\mathrm{OH})+\mathrm{H}^{*} \\
& \mathrm{H}^{*}+\mathrm{H}^{*} \rightarrow \mathrm{H}_{2} \\
& \mathrm{GO}+\mathrm{H}^{*} / \mathrm{H}_{2} \rightarrow \mathrm{RGO}+\mathrm{H}_{2} \mathrm{O} \\
& 2 \mathrm{Cu}(\mathrm{OH}) \rightarrow \mathrm{Cu}_{2} \mathrm{O}+\mathrm{H}_{2} \mathrm{O}
\end{aligned}
$$

The $\mathrm{RGO} / \mathrm{Cu}_{2} \mathrm{O} / \mathrm{Cu}$ composites thus obtained can be directly used as electrodes in supercapacitors, and their performance was assessed using cyclic voltammetry (CV), chronopotentiometry, and electrochemical impedance spectroscopy (EIS). CV has been considered to be a suitable tool for estimating the difference between the non-Faradaic and Faradaic reactions. CV measurements were conducted using a 3-electrode cell, in which $\mathrm{Pt}$ foil, $\mathrm{SCE}$, and as-synthesized $\mathrm{RGO} / \mathrm{Cu}_{2} \mathrm{O} / \mathrm{Cu}$ composites were used as the auxiliary electrode, reference electrode, and working electrode, respectively. Fig.7a shows the $\mathrm{CV}$ curves obtained from the $\mathrm{RGO} / \mathrm{Cu}_{2} \mathrm{O} / \mathrm{Cu}$ composites with a scan rate of $20 \mathrm{mV} \mathrm{s}^{-1}$, and Fig.7b shows the $\mathrm{CV}$ curves of the 
$\mathrm{RGO} / \mathrm{Cu}_{2} \mathrm{O} / \mathrm{Cu}-200$ sample obtained with different scan rates in the range of $5 \mathrm{mV} \mathrm{s}^{-1}$ to $100 \mathrm{mV} \mathrm{s}^{-1}$. All the $\mathrm{CV}$ loops clearly display a pair of redox peaks, suggesting that $\mathrm{RGO} / \mathrm{Cu}_{2} \mathrm{O} / \mathrm{Cu}$ composites have excellent capacitance $[58,59]$, which was contributed by double layer capacitors and pseudo capacitors in their structure. Furthermore, the $\mathrm{RGO} / \mathrm{Cu}_{2} \mathrm{O} / \mathrm{Cu}-200$ sample exhibits much better performance than the others (Fig.7a).

Fig. 8 shows the galvanostatic charge/discharge performance of the $\mathrm{RGO} / \mathrm{Cu}_{2} \mathrm{O}$ composites prepared at different temperatures. The specific capacitance $C_{s}$ (shown in Table 1) can be calculated, using the following equation [60]:

$$
\mathrm{C}_{\mathrm{s}}=\mathrm{I} \Delta \mathrm{t} / \Delta \mathrm{V}
$$

Where $\Delta \mathrm{V}(\mathrm{V})$ is the potential window, and $\mathrm{I}\left(\mathrm{A} \mathrm{g}^{-1}\right)$ is the discharge current density at time $\Delta \mathrm{t}(\mathrm{s})$.

Fig.8a and Table 1 clearly demonstrate that the capacitance obtained at current density of $1 \mathrm{~A} \mathrm{~g} \mathrm{~g}^{-1}$ increases as the sample preparation temperature increases from $160{ }^{\circ} \mathrm{C}\left(33.3 \mathrm{~F} \mathrm{~g}^{-1}\right)$, through $180{ }^{\circ} \mathrm{C}\left(57.0 \mathrm{~F} \mathrm{~g}^{-1}\right)$, to $200{ }^{\circ} \mathrm{C}\left(98.5 \mathrm{~F} \mathrm{~g}^{-1}\right)$, but it decreases when the temperature is further increased from $200{ }^{\circ} \mathrm{C}\left(98.5 \mathrm{~F} \mathrm{~g}^{-1}\right)$, through $220{ }^{\circ} \mathrm{C}\left(73.1 \mathrm{~F} \mathrm{~g} \mathrm{~g}^{-1}\right)$, to $240{ }^{\circ} \mathrm{C}\left(62.5 \mathrm{~F} \mathrm{~g}^{-1}\right)$. On increasing the current density from $1 \mathrm{~A}$ $\mathrm{g}^{-1}$ to $5 \mathrm{~A} \mathrm{~g}^{-1}$, the capacitance shows the same dependence on the temperature. In addition, at least $53 \%$ capacitance was retained at $5 \mathrm{~A} \mathrm{~g}^{-1}$ for all RGO-containing samples in comparison with the capacitance measured at current density of $1 \mathrm{~A} \mathrm{~g} \mathrm{~g}^{-1}$, as shown in Table 1 . For the $\mathrm{RGO} / \mathrm{Cu}_{2} \mathrm{O} / \mathrm{Cu}-200$ sample in particular, $88 \%$ capacitance (86.9 $\mathrm{F} \mathrm{g} \mathrm{g}^{-1}$ ) was retained when the current density was $3 \mathrm{~A} \mathrm{~g}^{-1}$, and over $64 \%$ 
capacitance $\left(63.2 \mathrm{~F} \mathrm{~g}^{-1}\right)$ was still retained even when a current density of $5 \mathrm{~A} \mathrm{~g}^{-1}$ was applied (Fig.8b and Table 1). Therefore, the sample prepared at $200{ }^{\circ} \mathrm{C}$ has the best performance, i.e. excellent discharge efficiency and electrochemically dynamic properties [61], which are consistent with the CV results.

Similar to a previous report, a pair of small plateaus with starting potential and ending potential close to those in the $\mathrm{CV}$ curves (Fig.7) appears in the charging-discharging curves (Fig.8b), indicating the existence of redox reactions during the charging-discharging process [62]. The plateau during the charging process lasts longer than the discharging, resulting in a low coulombic efficiency. A similar coulombic efficiency was also reported in the case of $\mathrm{CuO}$ [63], which is attributed to the inevitable transformation of cupric oxide into hydroxide in an alkaline solution [64, 65]. In addition, the charging/discharging voltage is significantly high for samples prepared at $220^{\circ} \mathrm{C}$ and $240{ }^{\circ} \mathrm{C}$. This could be attributed to the poor coating of relatively big $\mathrm{Cu}_{2} \mathrm{O}$ particles by $\mathrm{RGO}$ at high temperature, which leads to low conductivity of the composites. The cyclability of the $\mathrm{Cu}_{2} \mathrm{O} / \mathrm{RGO} / \mathrm{Cu}-200$ electrode was also assessed by 1000 continuous charging/discharging measurements at a current density of $1 \mathrm{~A} \mathrm{~g}^{-1}$ within the potential range of $-0.8-0 \mathrm{~V}$ (Fig. 9a). Although a clear drop occurred in the initial cycles, the specific capacitance is very stable after 150 cycles. The Coulombic efficiency increases from $40 \%$ to $100 \%$ with the cycles increasing to 350 cycles, and then keeps constant from 350 cycles to 1000 cycles (Fig. 9a).

Fig. 9b presents the Nyquist plots of various $\mathrm{RGO} / \mathrm{Cu}_{2} \mathrm{O} / \mathrm{Cu}$ electrodes in the 
frequency range of $10 \mathrm{kHz}$ to $0.01 \mathrm{~Hz}$ in $1 \mathrm{M} \mathrm{KOH}$ aqueous solution. Each impedance spectrum has a semicircular arc and a straight line for all the $\mathrm{RGO} / \mathrm{Cu}_{2} \mathrm{O} / \mathrm{Cu}$ and $\mathrm{Cu}_{2} \mathrm{O} / \mathrm{Cu}$ composites. The magnitude of the equivalent series resistance (ESR), determining the rate that the electrochemical supercapacitors (ESCs) can be charged/discharged, which is an important factor in determining the power density of ESCs, is obtained from the $\mathrm{x}$-intercept of the Nyquist plot. Obviously, the $\mathrm{RGO} / \mathrm{Cu}_{2} \mathrm{O} / \mathrm{Cu}-200$ composite has the smallest ESR value $(0.35 \Omega)$, and all the composite samples show smaller ESR values than $\mathrm{Cu}_{2} \mathrm{O} / \mathrm{Cu}$. These results indicate that the as-synthesized composites, especially the $\mathrm{RGO} / \mathrm{Cu}_{2} \mathrm{O} / \mathrm{Cu}-200$, have good rate capability, which is consistent with the $\mathrm{CV}$ and galvanostatic charge-discharg results.

The high-frequency semicircle is ascribed to the double-layer capacitance $\left(C_{d l}\right)$ in parallel with the charge transfer resistance $\left(R_{c t}\right)$ at the contact interface between the electrodes and the electrolyte solution $[66,67]$. The $R_{c t}$ values for all samples are smaller than $3.0 \Omega$, and there is no distinct difference between them. The slope at the lower frequencies represents the diffusive resistance of the electrolyte in electrode pores and the proton diffusion in the host material. It should be a vertical line in principle, which is parallel to the imaginary axis. However, except that of $\mathrm{RGO} / \mathrm{Cu}_{2} \mathrm{O} / \mathrm{Cu}-200$ sample, the slopes of other samples distinctly deviate from the expected vertical line due to electrode inhomogeneity and the existence of a "constant phase element" $[68,69]$. The large slope of the $\mathrm{RGO} / \mathrm{Cu}_{2} \mathrm{O} / \mathrm{Cu}-200$ sample suggests pure capacitive behavior and low diffusion resistance of ions in its electrode.

The excellent supercapacitor performance may be attributed to the unique 
structure of the $\mathrm{RGO} / \mathrm{Cu}_{2} \mathrm{O} / \mathrm{Cu}$ composites. As seen in the SEM images (Figs.5-6), a layer of $\mathrm{RGO}$ covered $\mathrm{Cu}_{2} \mathrm{O}$ particles has formed on the $\mathrm{Cu}$ substrates during the hydrothermal process. The entangled graphene sheets interact with the $\mathrm{Cu}_{2} \mathrm{O}$ layer underneath to form an open pore system, through which electrolyte ions can easily gain access to the surface graphene to form electrical double layers [70]. This structure leads to efficient utilization of such pseudo- and double-layer capacitors to produce electrical double layer and Faraday capacitance [71, 72]. As shown in Fig.5, only the $\mathrm{RGO} / \mathrm{Cu}_{2} \mathrm{O} / \mathrm{Cu}-200$ sample has a uniform RGO network that is well spread and in contact with the $\mathrm{Cu}_{2} \mathrm{O}$ layer. Thus a well-defined and stable interface is formed in this sample, which facilitates the ion diffusion and electrochemical reactions.

\section{Conclusions}

In summary, $\mathrm{RGO} / \mathrm{Cu}_{2} \mathrm{O}$ composite films were successfully synthesized on the surface of copper foil substrates through an in-situ redox reaction between the GO and the $\mathrm{Cu}$ foil, assisted by hydrothermal treatment. Due to its unique structure (i.e. RGO layer completely covered and in good contact with the $\mathrm{Cu}_{2} \mathrm{O}$ layer), the $\mathrm{RGO} / \mathrm{Cu}_{2} \mathrm{O} / \mathrm{Cu}$ electrode prepared at $200{ }^{\circ} \mathrm{C}$ exhibited a specific capacitance of $98.5 \mathrm{~F}$ $\mathrm{g}^{-1}$ at a discharge current density of $1 \mathrm{~A} \mathrm{~g}^{-1}$ and $63.2 \mathrm{~F} \mathrm{~g}^{-1}$ at $5 \mathrm{~A} \mathrm{~g}^{-1}$, respectively. The electrochemical performance of all the resultant $\mathrm{RGO} / \mathrm{Cu}_{2} \mathrm{O} / \mathrm{Cu}$ composites is much better than that of $\mathrm{Cu}_{2} \mathrm{O} / \mathrm{Cu}$. 
Acknowledgments: Financial support was provided by the National Natural Science Foundation of China (No.20504026), the Shanghai Natural Science Foundation (No.13ZR1411900), the Shanghai Leading Academic Discipline Project (B502), and the Shanghai Key Laboratory Project (08DZ2230500). Z. Li acknowledges support from the Australian Research Council through Discovery Projects DP130102699 and DP130102274. 


\section{References}

[1] P. Simon, Y. Gogotsi, Nat. Mater. 7 (2008) 845-854.

[2] K.V. Gurav, U.M. Patil, S.W. Shin, G.L. Agawane, M.P. Suryawanshi, S.M. Pawar, P.S.

Patil, C.D. Lokhande, J.H. Kim, J. Alloys Compd. 573 (2013) 27-31.

[3] T. Xiao, X. Hu, B. Heng, X. Chen, W. Huang, W. Tao, H. Wang, Y. Tang, X. Tan, X. Huang, J. Alloys Compd. 549 (2013) 147-151.

[4] X. Liu, B. Qu, F. Zhu, L. Gong, L. Su, L. Zhu, J. Alloys Compd. 560 (2013) 15-19.

[5] B. Senthilkumar, K. Vijaya Sankar, C. Sanjeeviraja, R. Kalai Selvan, J. Alloys Compd. 553 (2013) 350-357.

[6] M. Kaempgen, C.K. Chan, J. Ma, Y. Cui, G. Gruner, Nano Lett. 9 (2009) 1872-1876.

[7] C.C. Hu, W.C. Chen, K.H. Chang, J. Electrochem. Soc. 151 (2004) A281-A290.

[8] C.C. Hu, K.H. Chang, M.C. Lin, Y.T. Wu, Nano Lett. 6 (2006) 2690-2695.

[9] T.P. Gujar, V.R. Shinde, C.D. Lokhande, W.Y. Kim, K.D. Jung, O.S. Joo, Electrochem. Commun. 9 (2007) 504-510.

[10] Z. Song, W. Liu, M. Zhao, Y. Zhang, G. Liu, C. Yu, J. Qiu, J. Alloys Compd. 560 (2013) $151-155$.

[11] J.H. Shin, H.M. Park, J.Y. Song J. Alloys Compd. 551 (2013) 451-455.

[12] A. Ramadoss, S.J. Kim, J. Alloys Compd. 561 (2013) 262-267.

[13] H.B. Li, M.H. Yu, F.X. Wang, P. Liu, Y. Liang, J. Xiao, C.X. Wang, Y.X. Tong, G.W. Yang, , Nat. Commun. 4 (2013) 1894.

[14] D.P. Dubal, D.S. Dhawale, R.R. Salunkhe, V.S. Jamdade, C.D. Lokhande, J. Alloys Compd. 492 (2010) 26-30. 
[15] U.M. Patil, K.V. Gurav, V.J. Fulari, C.D. Lokhande, O.S. Joo, J. Power Sources 188 (2009) $338-342$.

[16] K.S. Kim, Y. Zhao, H. Jang, S.Y. Lee, J.M. Kim, K.S. Kim, J.H. Ahn, P. Kim, J.Y. Choi, B. H. Hong, Nature 457 (2009) 706-710.

[17] C. Lee, X. Wei, J.W. Kysar, J. Hone, Science 321 (2008) 385-388.

[18] E.W. Hill, A.K. Geim, K.Novoselov, F. Schedin, P. Blake, Magnetics, IEEE Trans. Magn. 42 (2006) 2694-2696.

[19] N. Tombros, C. Jozsa, M. Popinciuc, H.T. Jonkman, B.J. van Wees, Nature 448 (2007) $571-574$.

[20] Z. Wang, C. Ma, H. Wang, Z. Liu, Z. Hao, J. Alloys Compd. 552 (2013) 486-491.

[21] C. Liang, M. Gao, H. Pan, Y. Liu, M. Yan J. Alloys Compd. 575 (2013) 246-256.

[22] L.Q. Lu, Y. Wang, Electrochem. Commun. 14 (2012) 82-85.

[23] W. Zhou, J. Zhu, C. Cheng, J. Liu, H. Yang, C. Cong, C. Guan, X. Jia, H.J. Fan, Q. Yan, C.M. Li, T. Yu, Energy Environ. Sci. 4 (2011) 4954-4961.

[24] S.D. Seo, D.H. Lee, J.C. Kim, G.H. Lee, D.W. Kim, Ceram. Int. 39 (2013) 1749-1755.

[25] J. Zhou, L. Ma, H. Song, B. Wu, X. Chen, Electrochem. Commun. 13 (2011) 1357-1360.

[26] J.W. Ko, S.W. Kim, J. Hong, J. Ryu, K. Kang, C.B. Park, Green Chem. 14 (2012) 2391-2394.

[27] L.Q. Lu, Y. Wang, J. Mater. Chem. 21 (2011) 17916-17921.

[28] B. Wang, X.L. Wu, C.Y. Shu, Y.G. Guo, C.R. Wang, J. Mater. Chem. 20 (2010) 10661-10664.

[29] A.K. Rai, L.T. Anh, J. Gim, V. Mathew, J. Kang, B.J. Paul, N.K. Singh, J. Song, J. Kim, J. 
Power Sources, 244 (2013) 435-441.

[30] Y.J. Mai, X.L. Wang, J.Y. Xiang, Y.Q. Qiao, D. Zhang, C.D. Gu, J.P. Tu, Electrochim. Acta 56 (2011) 2306-2311.

[31] K.H. Kim, D.W. Jung, V.H. Pham, J.S. Chung, B.S. Kong, J.K. Lee, K. Kim, E.S. Oh, Electrochim. Acta 69 (2012) 358-363.

[32] W. Liu, G. Chen, G. He, W. Zhang, J. Nanopart. Res. 13 (2011) 2705-2713.

[33] Y. Zhang, X. Wang, L. Zeng, S. Song, D. Liu, Dalton Trans. 41 (2012) 4316-4319.

[34] C. Xu, X. Wang, L. Yang, Y. Wu, J. Solid State Chem. 182 (2009) 2486-2490.

[35] B. Li, H. Cao, G. Yin, Y. Lu, J. Yin, J. Mater. Chem. 21 (2011) 10645-10648.

[36] A. Pendashteh, M.F. Mousavi, M.S. Rahmanifar, Electrochim. Acta 88 (2013) 347-357.

[37] B. Zhao, P. Liu, H. Zhuang, Z. Jiao, T. Fang, W. Xu, B. Lu, Y. Jiang, J. Mater. Chem. A 1 (2013) 367-373.

[38] F. Zhang, Y. Li, Y.e. Gu, Z. Wang, C. Wang, Microchim. Acta 173 (2011) 103-109.

[39] Y. Qian, F. Ye, J. Xu, Z.G. Le, Int. J. Electrochem. Sci. 7 (2012) 10063-10073.

[40] W.S. Hummers, R.E. Offeman, J. Am. Chem. Soc. 80 (1958) 1339-1339.

[41] Y. Xu, H. Bai, G. Lu, C. Li, G. Shi, J. Am. Chem. Soc. 130 (2008) 5856-5857.

[42] A. Lamberti, M. Destro, S. Bianco, M. Quaglio, A. Chiodoni, C. F. Pirri, C. Gerbaldi, Electrochim. Acta 70 (2012) 62-68.

[43] H.K. Jeong, Y.P. Lee, R.J. Lahaye, M.H. Park, K.H. An, I.J. Kim, C.W. Yang, C.Y. Park, R.S. Ruoff, Y.H. Lee, J. Am. Chem. Soc. 130 (2008) 1362-1366.

[44] Y. Xu, H. Bai, G. Lu, C. Li, G. Shi, J. Am. Chem. Soc. 130 (2008) 5856-5857.

[45] S. Deng, V. Tjoa, H.M. Fan, H.R. Tan, D.C. Sayle, M. Olivo, S. Mhaisalkar, J. Wei, C.H. 
Sow, J. Am. Chem. Soc. 134 (2012) 4905-4917.

[46] C. Hou, H. Quan, Y. Duan, Q. Zhang, H. Wang, Y. Li, Nanoscale 5 (2013) 1227-1232.

[47] D.C. Elias, R.R. Nair, T.M.G. Mohiuddin, S.V. Morozov, P. Blake, M.P. Halsall, A.C. Ferrari, D.W. Boukhvalov, M.I. Katsnelson, A.K. Geim, K.S. Novoselov, Science 323 (2009) 610-613.

[48] S.Z. Zu, B.H. Han, J. Phys. Chem. C 113 (2009) 13651-13657.

[49] S. Pei, H.M. Cheng, Carbon 50 (2012) 3210-3228.

[50] A.C. Ferrari, J.C. Meyer, V. Scardaci, C. Casiraghi, M. Lazzeri, F. Mauri, S. Piscanec, D. Jiang, K.S. Novoselov, S. Roth, A.K. Geim, Phys. Rev. Lett. 97 (2006) 187401.

[51] Y. Qi, J.R. Eskelsen, U. Mazur, K.W. Hipps, Langmuir 28 (2012) 3489-3493.

[52] J.N. Nian, C.C. Tsai, P.C. Lin, H. Teng, J. Electrochem. Soc. 156 (2009) H567-H573.

[53] T. Ghodselahi, M.A. Vesaghi, A. Shafiekhani, A. Baghizadeh, M. Lameii, Appl. Surf. Sci. 255 (2008) 2730-2734.

[54] P. Grez, F. Herrera, G. Riveros, A. Ramírez, R. Henríquez, E. Dalchiele, R. Schrebler, phys. status solidi A 209 (2012) 2470-2475.

[55] J.Y. Park, Y.S. Jung, J. Cho, W.K. Choi, Appl. Surf. Sci. 252 (2006) 5877-5891.

[56] Y. Bai, R.B. Rakhi, W. Chen, H.N. Alshareef, J. Power Sources 233 (2013) 313-319.

[57] T. Lu, Y. Zhang, H. Li, L. Pan, Y. Li, Z. Sun, Electrochim. Acta 55 (2010) 4170-4173.

[58] Y. Zhang, H. Li, L. Pan, T. Lu, Z. Sun, J. Electroanal. Chem. 634 (2009) 68-71.

[59] Y. Wang, Z. Shi, Y. Huang, Y. Ma, C. Wang, M. Chen, Y. Chen, J. Phys. Chem. C 113 (2009) 13103-13107.

[60] Y.M. Chen, J.H. Cai, Y.S. Huang, K.Y. Lee, D.S. Tsai, Nanotechnology 22 (2011) 115706. 
[61] T. Lu, L. Pan, H. Li, G. Zhu, T. Lv, X. Liu, Z. Sun, T. Chen, D.H.C. Chua, J. Alloys Compd. 509 (2011) 5488-5492.

[62] W. Zhang, F. Liu, Q. Li, Q. Shou, J. Cheng, L. Zhang, B.J. Nelson, X. Zhang, Phys. Chem. Chem. Phys. 14 (2012) 16331-16337.

[63] A. Pendashteh, M.F. Mousavi, M.S. Rahmanifar, Electrochim. Acta 88 (2013) 347-357.

[64] G.L. Wang, J.C. Huang, S.L. Chen, Y.Y. Gao, D.X. Cao, J. Power Sources 196 (2011) 5756-5760.

[65] R. Bogdanowicz, J. Ryl, K. Darowicki, B.B. Kosmowski, J. Solid State Electrochem. 13 (2009) 1639-1644.

[66] X.Z. Wang, M.G. Li, Y.W. Chen, R.M. Cheng, S.M. Huang, L.K. Pan, Z. Sun, Appl. Phys. Lett. 89 (2006) 053127-053123.

[67] M. Zhi, A. Manivannan, F. Meng, N. Wu, J. Power Sources 208 (2012) 345-353.

[68] Y. Gao, L. Pan, H. Li, Y. Zhang, Z. Zhang, Y. Chen, Z. Sun, Thin Solid Films 517 (2009) 1616-1619.

[69] G.J. Brug, M. Sluyters-Rehbach, J.H. Sluyters, A. Hemelin, J. Electroanal. Chem. 181 (1984) 245-266.

[70] W. Lv, D.M. Tang, Y.B. He, C.H. You, Z.Q. Shi, X.C. Chen, C.M. Chen, P.X. Hou, C. Liu, Q.H. Yang, ACS Nano 3 (2009) 3730-3736.

[71] Z.S. Wu, W. Ren, D.W. Wang, F. Li, B. Liu, H.M. Cheng, ACS Nano 4 (2010) 5835-5842.

[72] Z. Fan, J. Yan, L. Zhi, Q. Zhang, T. Wei, J. Feng, M. Zhang, W. Qian, F. Wei, Adv. Mater. 22 (2010) 3723-3728. 


\section{Scheme and Figure captions}

Scheme 1. Schematic illustration of the synthesis of $\mathrm{RGO} / \mathrm{Cu}_{2} \mathrm{O} / \mathrm{Cu}$ in polytetrafluoroethylene (PTFE, Teflon ${ }^{\circledR}$ ) lined autoclave.

Fig.1 XRD patterns of $\mathrm{RGO} / \mathrm{Cu}_{2} \mathrm{O} / \mathrm{Cu}-160, \mathrm{RGO} / \mathrm{Cu}_{2} \mathrm{O} / \mathrm{Cu}-180, \mathrm{RGO} / \mathrm{Cu}_{2} \mathrm{O} / \mathrm{Cu}-200$, $\mathrm{RGO} / \mathrm{Cu}_{2} \mathrm{O} / \mathrm{Cu}-220, \mathrm{RGO} / \mathrm{Cu}_{2} \mathrm{O} / \mathrm{Cu}-240$, and $\mathrm{Cu}$ foil and pure $\mathrm{RGO}$ prepared by the hydrothermal method at $200^{\circ} \mathrm{C}$ for $24 \mathrm{~h}$.

Fig.2 FT-IR spectra of $\mathrm{RGO} / \mathrm{Cu}_{2} \mathrm{O} / \mathrm{Cu}-160, \mathrm{RGO} / \mathrm{Cu}_{2} \mathrm{O} / \mathrm{Cu}-180, \mathrm{RGO} / \mathrm{Cu}_{2} \mathrm{O} / \mathrm{Cu}-200$, $\mathrm{RGO} / \mathrm{Cu}_{2} \mathrm{O} / \mathrm{Cu}-220, \mathrm{RGO} / \mathrm{Cu}_{2} \mathrm{O} / \mathrm{Cu}-240$, and $\mathrm{GO}$.

Fig.3 Raman spectra of $\mathrm{RGO} / \mathrm{Cu}_{2} \mathrm{O} / \mathrm{Cu}-160, \mathrm{RGO} / \mathrm{Cu}_{2} \mathrm{O} / \mathrm{Cu}-180, \mathrm{RGO} / \mathrm{Cu}_{2} \mathrm{O} / \mathrm{Cu}-200$, $\mathrm{RGO} / \mathrm{Cu}_{2} \mathrm{O} / \mathrm{Cu}-220, \mathrm{RGO} / \mathrm{Cu}_{2} \mathrm{O} / \mathrm{Cu}-240$, pure $\mathrm{RGO}$ prepared by hydrothermal treatment at $200{ }^{\circ} \mathrm{C}$ for $24 \mathrm{~h}$, and GO.

Fig.4 XPS spectra of $\mathrm{RGO} / \mathrm{Cu}_{2} \mathrm{O} / \mathrm{Cu}-160, \mathrm{RGO} / \mathrm{Cu}_{2} \mathrm{O} / \mathrm{Cu}-180, \mathrm{RGO} / \mathrm{Cu}_{2} \mathrm{O} / \mathrm{Cu}-200$, $\mathrm{RGO} / \mathrm{Cu}_{2} \mathrm{O} / \mathrm{Cu}-220, \mathrm{RGO} / \mathrm{Cu}_{2} \mathrm{O} / \mathrm{Cu}-240$, pure $\mathrm{RGO}$ prepared by hydrothermal treatment at $200{ }^{\circ} \mathrm{C}$ for $24 \mathrm{~h}$, and GO: C 1s peaks of (a) GO, (b) RGO after hydrothermal treatment, and (c) $\mathrm{RGO} / \mathrm{Cu}_{2} \mathrm{O} / \mathrm{Cu}-200$; (d) survey spectra of all samples; (e) $\mathrm{Cu} 2 \mathrm{p}_{3 / 2}$ and $\mathrm{Cu} 2 \mathrm{p}_{1 / 2}$ peaks of $\mathrm{RGO} / \mathrm{Cu}_{2} \mathrm{O} / \mathrm{Cu}-200$ and $\mathrm{Cu}$ foil; (f) $\mathrm{Cu} \mathrm{LMM} \mathrm{X}$-ray induced Auger peaks of $\mathrm{RGO} / \mathrm{Cu}_{2} \mathrm{O} / \mathrm{Cu}-200$ and copper foil.

Fig.5 FESEM images of (a) $\mathrm{RGO} / \mathrm{Cu}_{2} \mathrm{O} / \mathrm{Cu}-200$, (b) $\mathrm{Cu}$ foil after hydrothermal treatment, (c) tilted view of $\mathrm{RGO} / \mathrm{Cu}_{2} \mathrm{O} / \mathrm{Cu}-200$, and (d) pure graphene hydrothermally prepared at $200{ }^{\circ} \mathrm{C}$.

Fig.6 FESEM images of surface and tilted views of (a-b) $\mathrm{RGO} / \mathrm{Cu}_{2} \mathrm{O} / \mathrm{Cu}-160$, (c-d) 
$\mathrm{RGO} / \mathrm{Cu}_{2} \mathrm{O} / \mathrm{Cu}-180$, (e-f) $\mathrm{RGO} / \mathrm{Cu}_{2} \mathrm{O} / \mathrm{Cu}-220$, and (g-h) $\mathrm{RGO} / \mathrm{Cu}_{2} \mathrm{O} / \mathrm{Cu}-240$.

Fig.7 Cyclic voltammograms of (a) $\mathrm{RGO} / \mathrm{Cu}_{2} \mathrm{O} / \mathrm{Cu}-160,-180,-200,-220$, and -240 at scan rate $=20 \mathrm{mV} / \mathrm{s}$; and $(\mathrm{b}) \mathrm{RGO} / \mathrm{Cu}_{2} \mathrm{O} / \mathrm{Cu}-200$ electrode at different scan rates in 1 $\mathrm{M} \mathrm{KOH}$ electrolyte.

Fig.8 Galvanostatic charging/discharging curves of (a) $\mathrm{RGO} / \mathrm{Cu}_{2} \mathrm{O} / \mathrm{Cu}-160,-180$, $-200,-220$, and -240 at a current density of $1 \mathrm{~A} \mathrm{~g} \mathrm{~g}^{-1}$; and (b) $\mathrm{RGO} / \mathrm{Cu}_{2} \mathrm{O} / \mathrm{Cu}-200$ electrode at various current densities in $1 \mathrm{M} \mathrm{KOH}$ electrolyte.

Fig.9 (a) Cycling performance and coulombic efficiency of $\mathrm{RGO} / \mathrm{Cu}_{2} \mathrm{O} / \mathrm{Cu}-200$ electrode at a current density of $1 \mathrm{~A} \cdot \mathrm{g}^{-1}$ in $1 \mathrm{M} \mathrm{KOH}$ electrolyte. (b) Nyquist plots of experimental impedance data for $\mathrm{RGO} / \mathrm{Cu}_{2} \mathrm{O} / \mathrm{Cu}-160,-180,-200,-220$, and -240 nanocomposite electrodes and $\mathrm{Cu}_{2} \mathrm{O} / \mathrm{Cu}-200$ electrode in the frequency range of 100 $\mathrm{kHz}$ to $0.01 \mathrm{~Hz}$. The inset contains the magnified plots at high frequency.

Table 1. Specific capacitance of $\mathrm{RGO} / \mathrm{Cu}_{2} \mathrm{O} / \mathrm{Cu}$ composites prepared at 160,180 , 200, 220, and $240{ }^{\circ} \mathrm{C}$ at different current densities. 

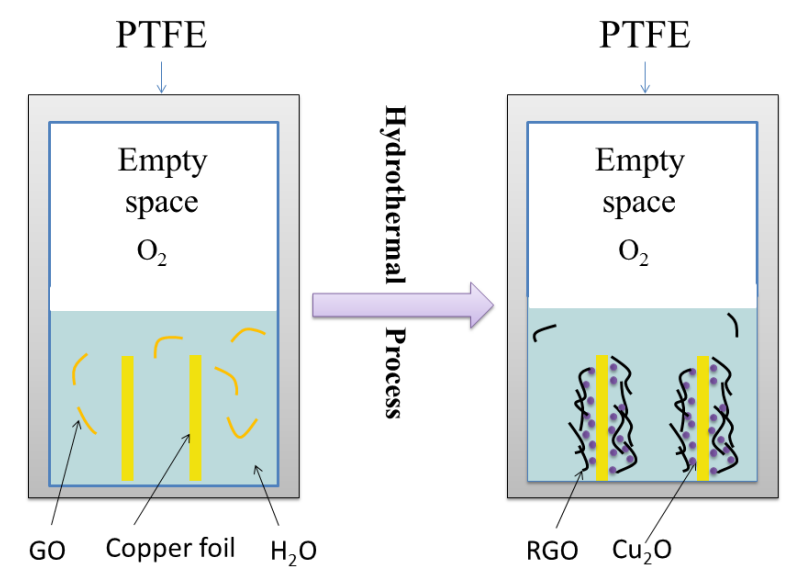

Scheme 1 


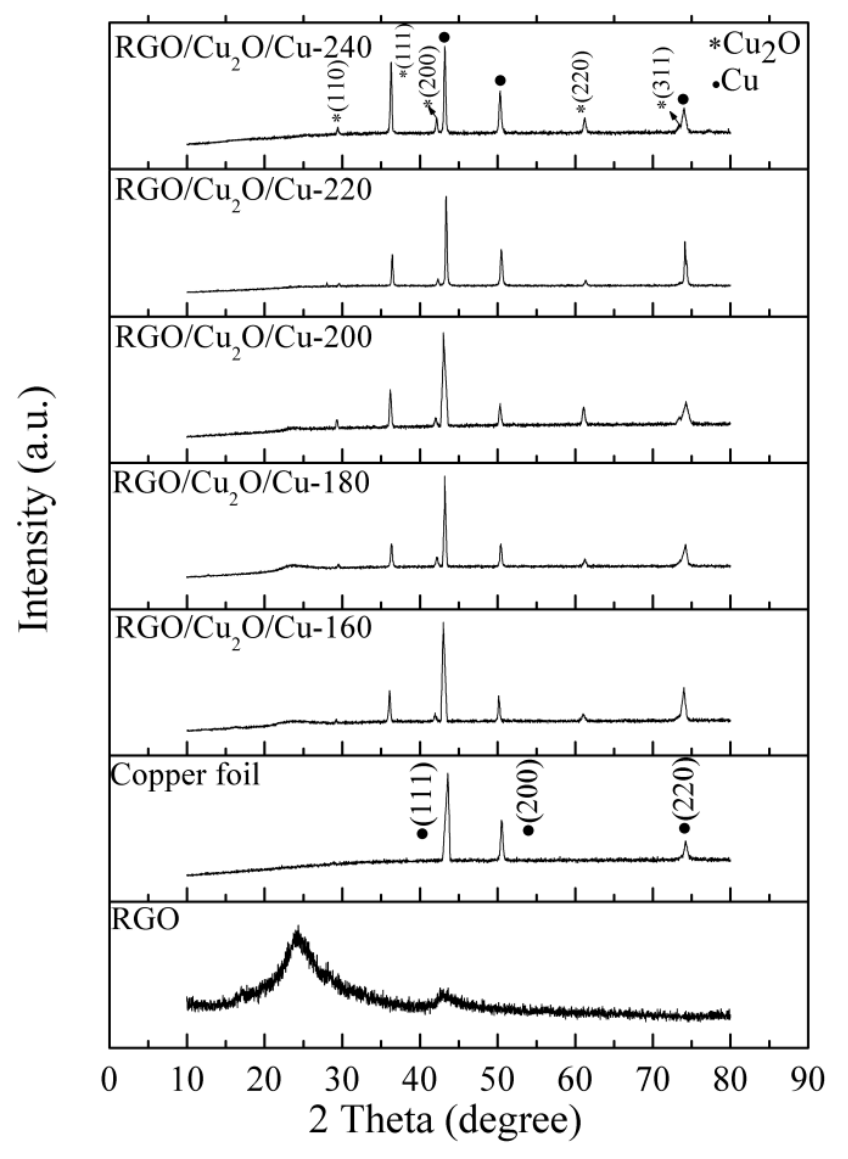

Fig. 1 


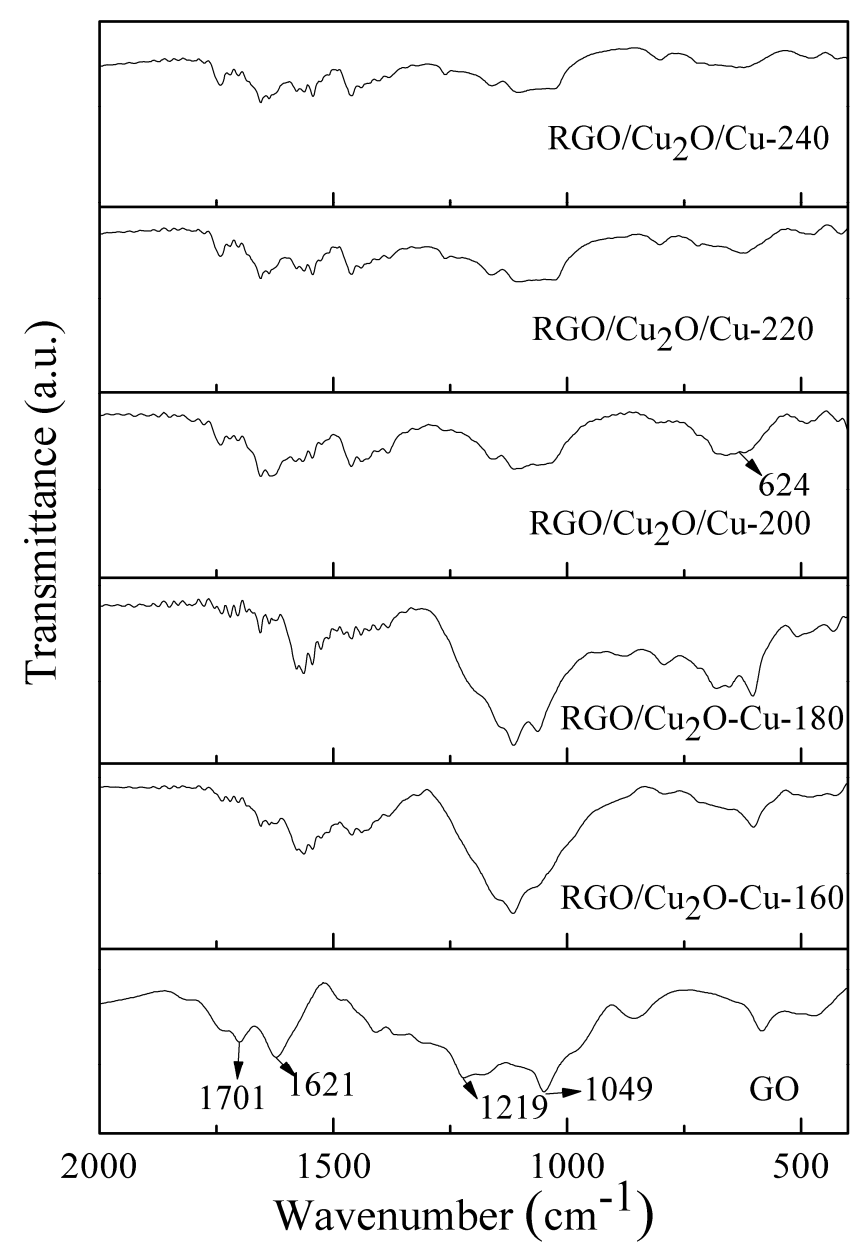

Fig. 2 


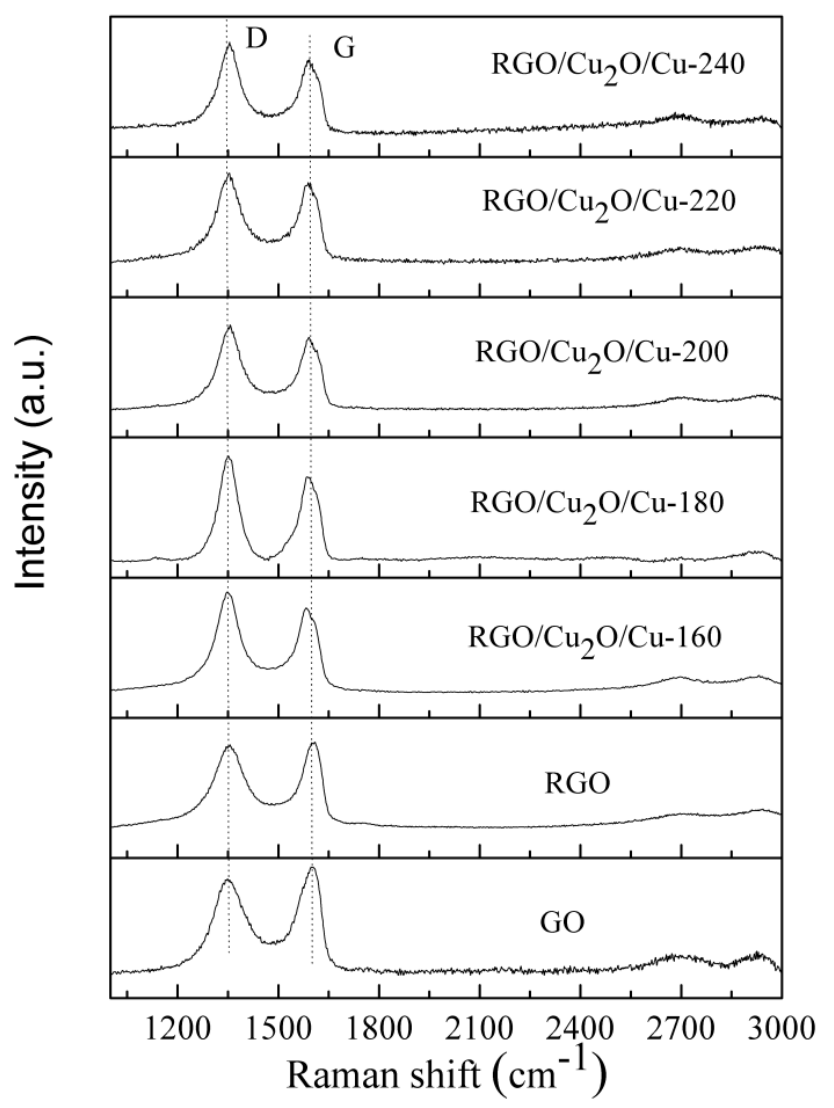

Fig. 3 

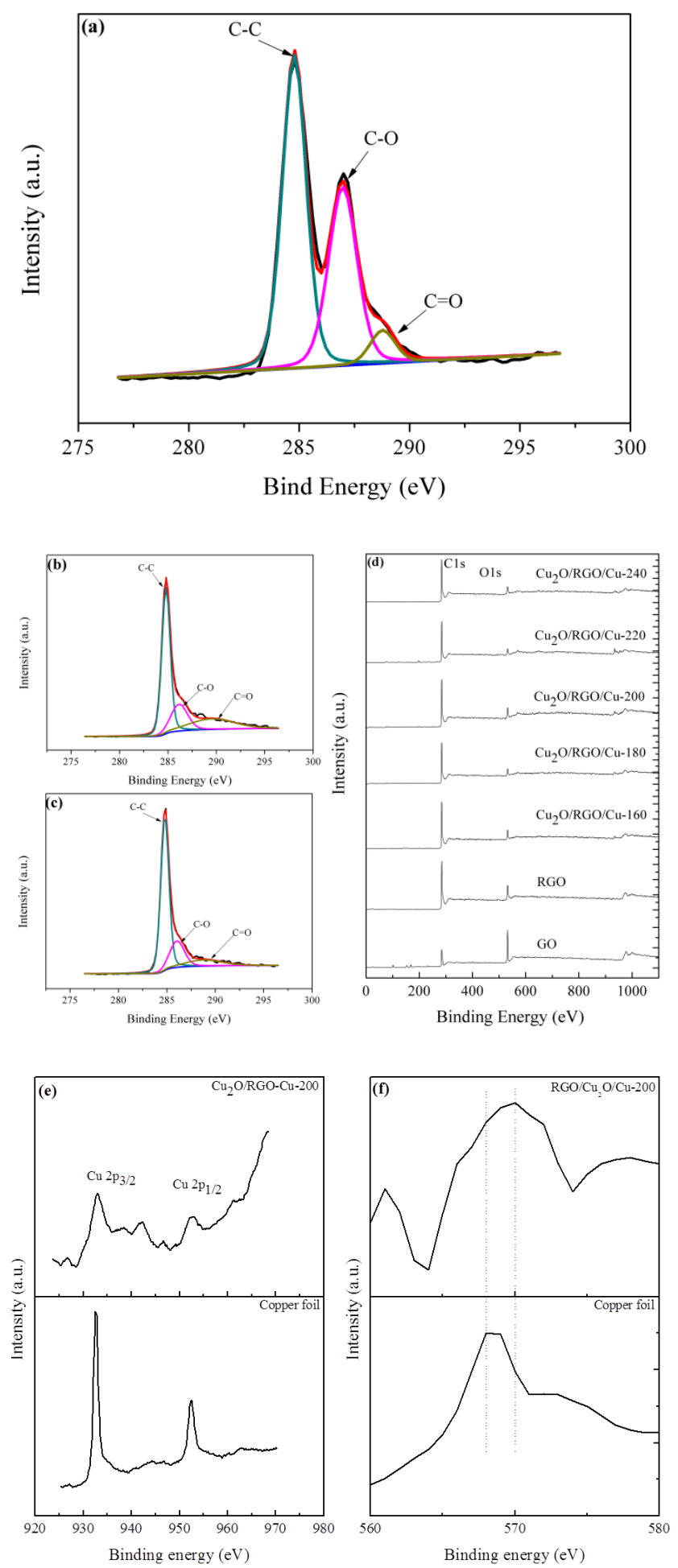

Fig. 4 


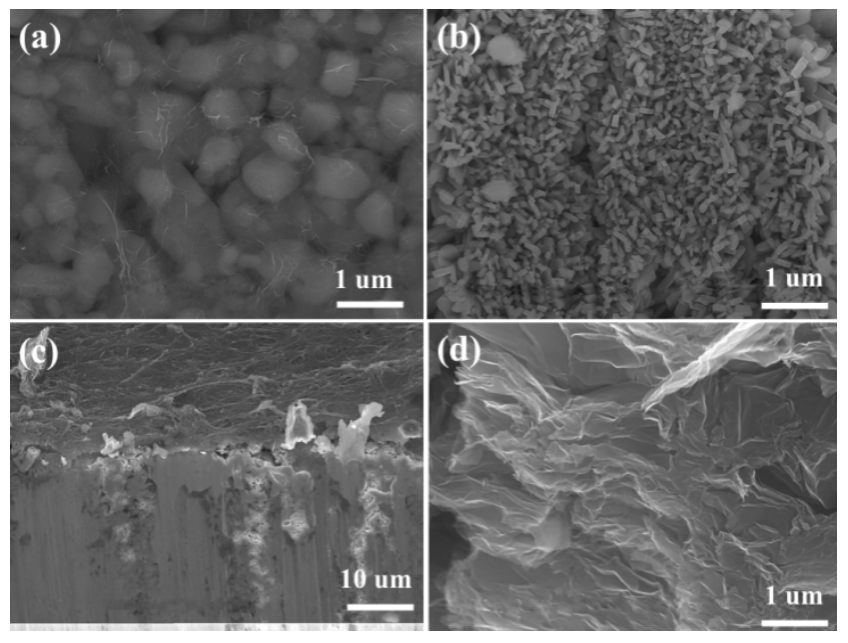

Fig. 5 


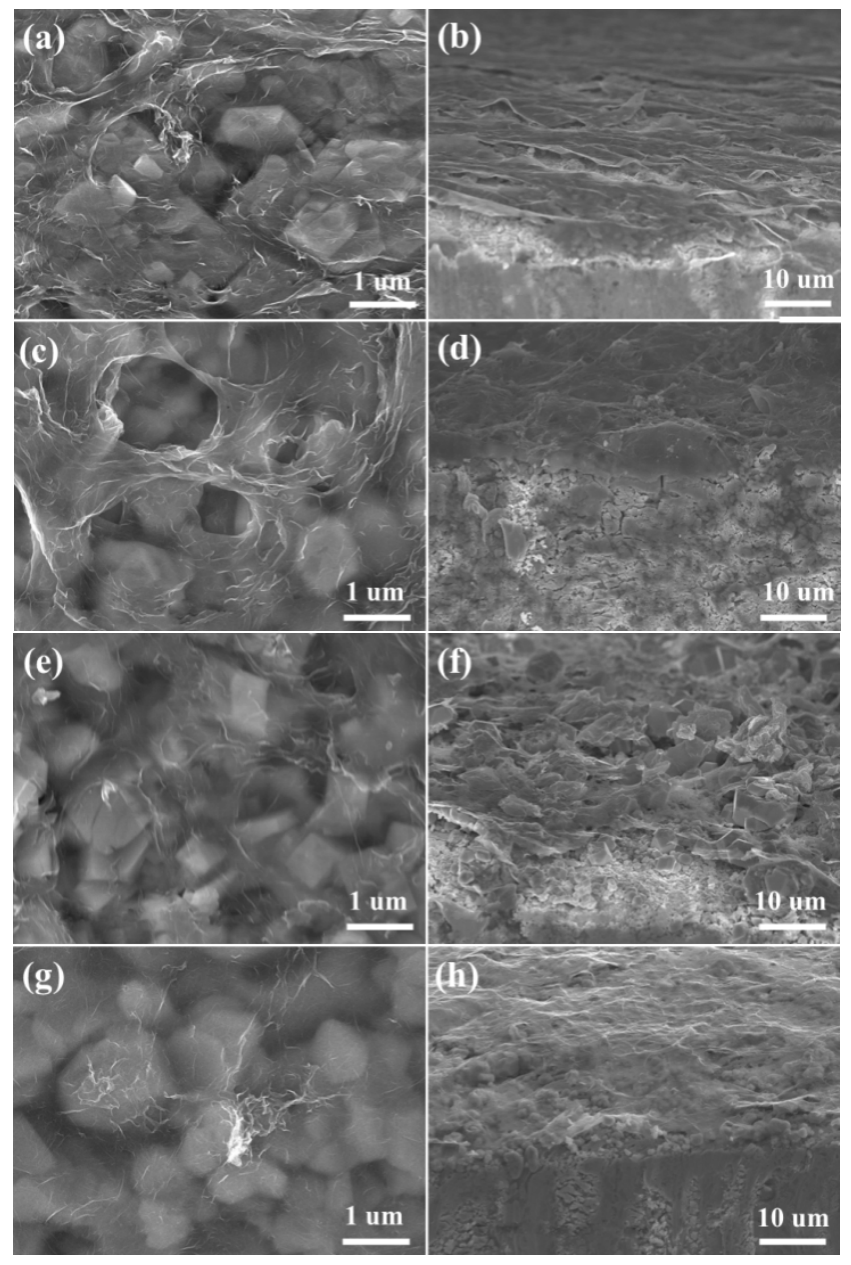

Fig. 6 

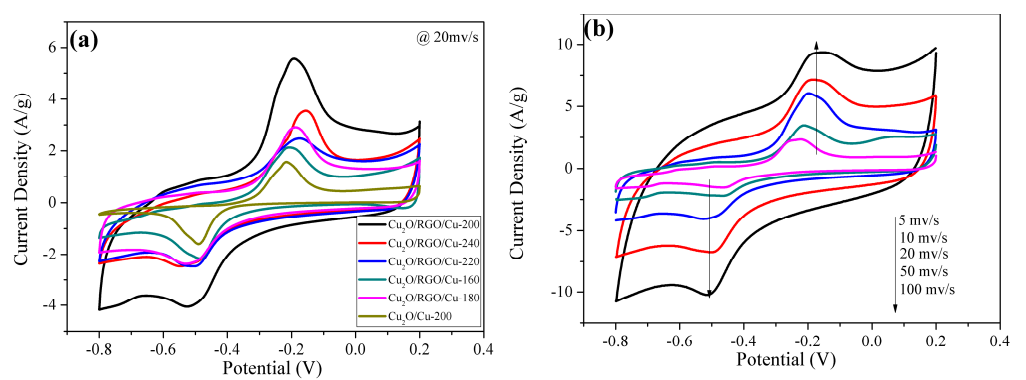

Fig. 7 

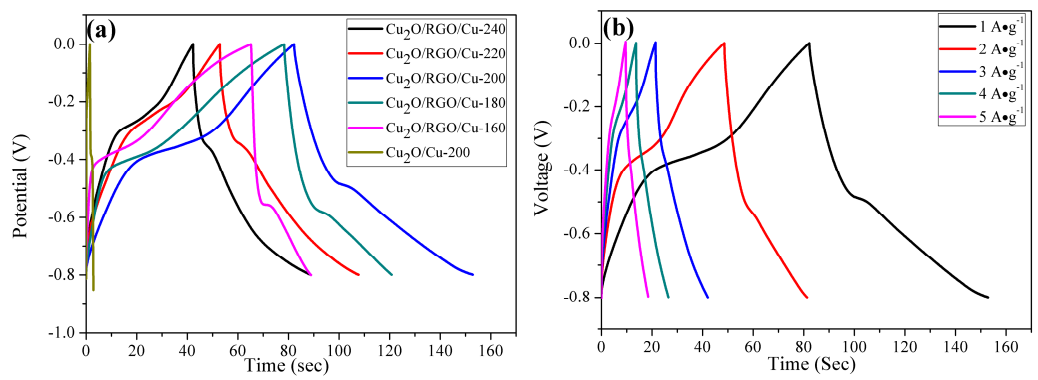

Fig. 8 

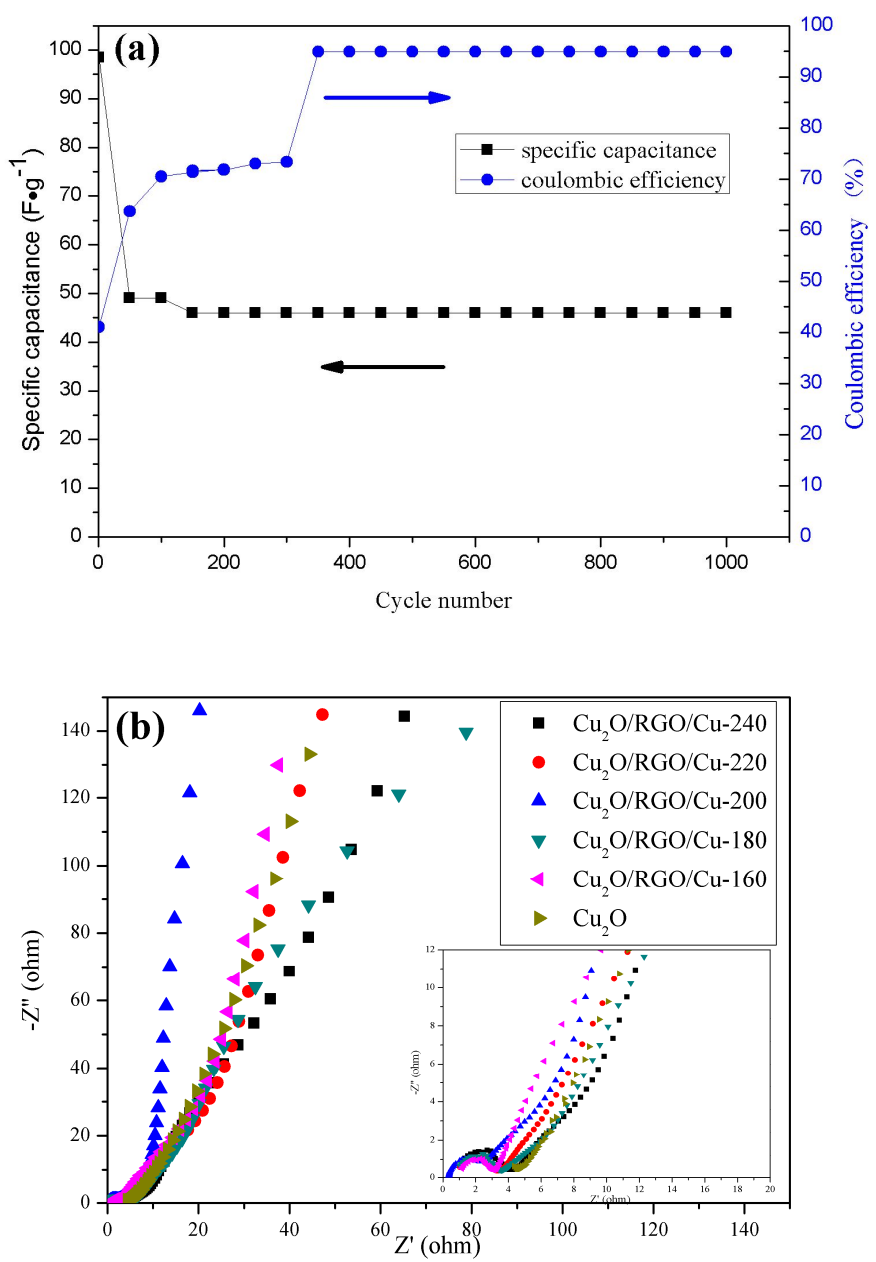

Fig.9 
Table 1

\begin{tabular}{|c|c|c|c|c|c|}
\hline \multirow{2}{*}{ Sample } & \multicolumn{5}{|c|}{ Specific capacitance $\left(\mathrm{F} \mathrm{g}^{-1}\right)$} \\
\hline & $1 \mathrm{Ag}^{-1}$ & $2 \mathrm{Ag}^{-1}$ & $3 \mathrm{Ag}^{-1}$ & $4 \mathrm{Ag}^{-1}$ & $5 \mathrm{Ag}^{-1}$ \\
\hline $\mathrm{RGO} / \mathrm{Cu}_{2} \mathrm{O} / \mathrm{Cu}-160$ & 33.3 & 18.9 & 26.2 & 20.5 & 18.7 \\
\hline $\mathrm{RGO} / \mathrm{Cu}_{2} \mathrm{O} / \mathrm{Cu}-180$ & 57.0 & 50.7 & 42.6 & 41.8 & 40.6 \\
\hline $\mathrm{RGO} / \mathrm{Cu}_{2} \mathrm{O} / \mathrm{Cu}-200$ & 98.5 & 91.9 & 86.9 & 71.8 & 63.2 \\
\hline $\mathrm{RGO} / \mathrm{Cu}_{2} \mathrm{O} / \mathrm{Cu}-220$ & 73.1 & 61.7 & 51.5 & 44.5 & 40.1 \\
\hline $\mathrm{RGO} / \mathrm{Cu}_{2} \mathrm{O} / \mathrm{Cu}-240$ & 62.5 & 60.3 & 47.3 & 41.4 & 33.2 \\
\hline
\end{tabular}

